\title{
"CAN I NOT WEAR MY HIJAB IN PEACE?": UNDERSTANDING YOUNG MUSLIM GIRLS REASON FOR AND EXPERIENCES OF WEARING THE HIJAB
}

by

Farheen Khan

M.A. (Psychology), Mumbai University, India, 2001

\author{
A Major Research Paper \\ presented to Ryerson University
}

in partial fulfillment of the requirements for the degree of

\author{
Master of Arts \\ in the Program of \\ Early Childhood Studies
}

Toronto, Ontario, Canada, 2009

(C) Farheen Khan 2009 


\section{Author's Declaration}

I hereby declare that I am the sole author of this major research paper.

I authorize Ryerson University to lend this paper to other institutions or individuals for the purpose of scholarly research.

Signature

I further authorize Ryerson University to reproduce this paper by photocopying or by other means, in total or in part, at the request of other institutions or individuals for the purpose of scholarly research.

Signature 


\title{
"CAN I NOT WEAR MY HIJAB IN PEACE?": UNDERSTANDING YOUNG MUSLIM GIRLS' REASONS FOR AND EXPERIENCES OF WEARING THE HIJAB
}

\begin{abstract}
The aim of this research paper was to explore the reasons for and experiences of young Muslim girls wearing the hijab. Their decision to wear the hijab is examined by exploring the concept of choice within the framework of socialization. The participants included 4 young Muslim girls in the age range of $11-13$ wearing the hijab and attending Canadian public school. Focus group and individual interviews were used for data collection. The results showed that religion was the primary reason why these girls chose to wear the hijab followed by their desire to develop a cultural identity and to represent Islam in the North American society. Family, peers and media were found to have an effect on their decision to wear the hijab. The girls narrated positive as well as negative experiences in and out of school, but were determined in their decision to wear the hijab and were happy with their decision. The implications and limitations of the study indicate a need for future research on this topic.
\end{abstract}

Key words: Young Muslim Girls, Hijab, Canadian Public Schools, Reasons, Experiences. 


\section{Acknowledgements}

First of all I thank ALLAH (SWT) for blessing me with all the wonderful gifts life has to offer and giving me this opportunity to enhance my knowledge.

I would like to thank my family, especially my husband, Mazhar, whose support and patience kept me going on.

I am deeply indebted to my wonderful supervisor Dr. Mehrunissa Ali for her patient guidance and constant support without which this research paper would not have been possible. I would like to thank my second-reader Dr. Sedef Arat-Koç whose insightful feedback enriched my paper further. Special thanks to Dr. Patricia Corson who agreed to chair my oral exam at a very short notice.

I take this opportunity to thank Dr. Judith Bernhard (Program Director) for giving us all the opportunity to be a part of this wonderful program. It was a great learning experience.

I would also like to thank all my professors and friends who provided a rich learning environment and support throughout the program.

I also want to express my gratitude to all my participants and their parents for trusting me and sharing their experiences with me.

Lastly I dedicate my research paper to my two lovely sons Uzair and Umair. 
AUTHOR'S DECLARATION ...................................................... ii

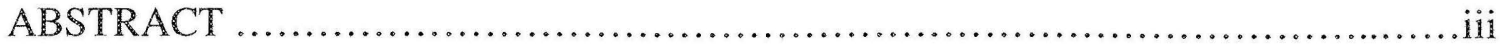

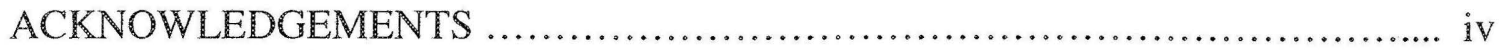

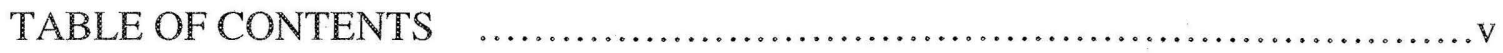

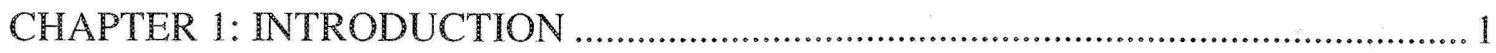

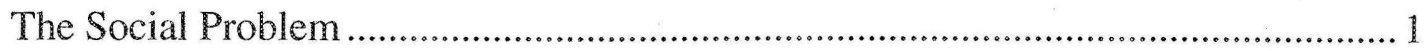

Why is it important to address this problem? .......................................................... 2

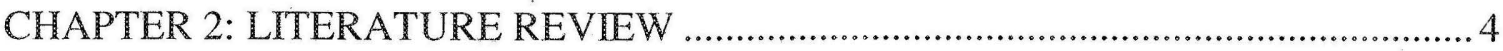

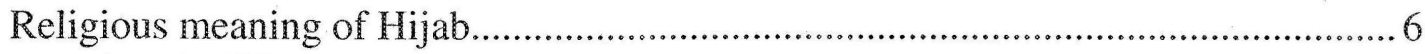

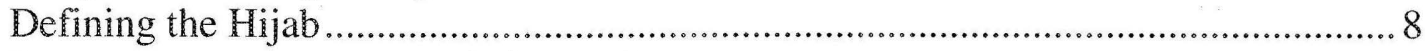

Perceptions of the Hijab in Western Society ............................................................. 9

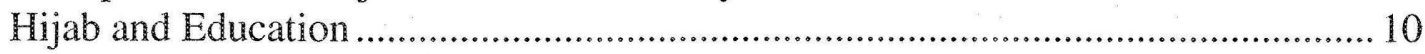

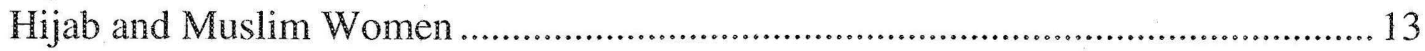

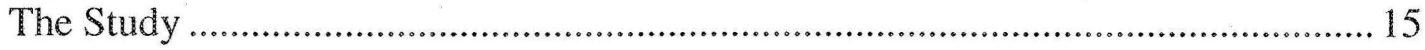

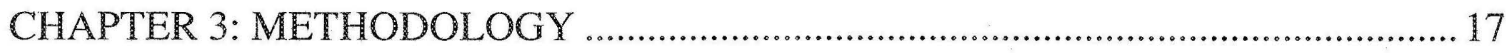

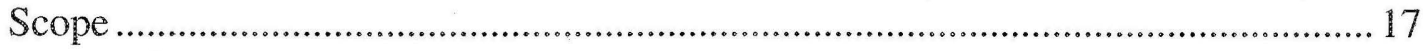

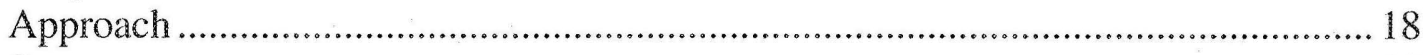

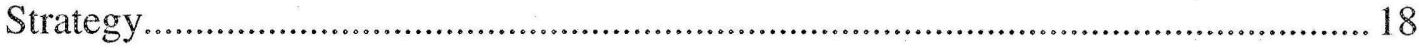

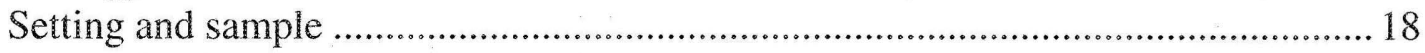

Researcher Self Disclosure.................................................................................... 19

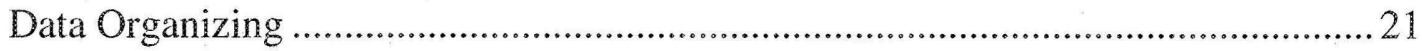

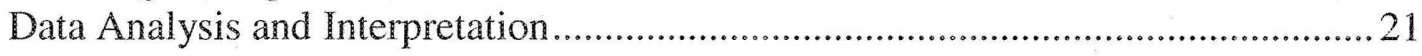

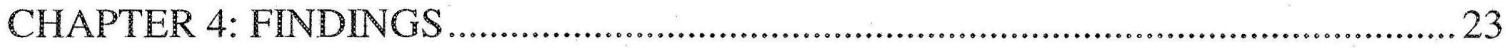

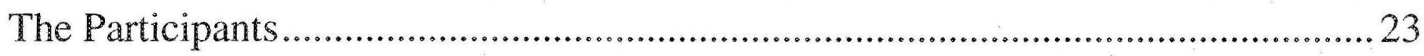

Reasons For Wearing The Hijab: Religion, Culture And Self Identity .................... 27

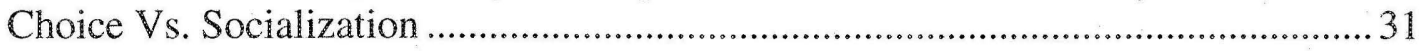

Personal Choice and Family Expectations: ................................................... 31

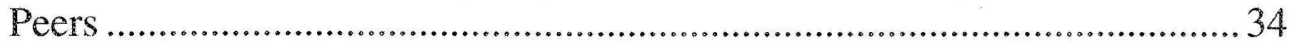

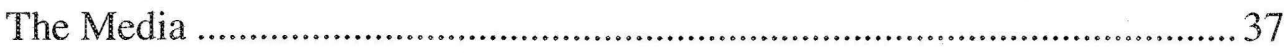

Experiences: Living With The Hijab ......................................................................... 39

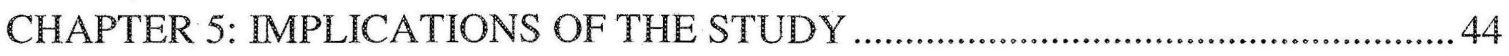

Limitations and Prospects for future research............................................................... 45

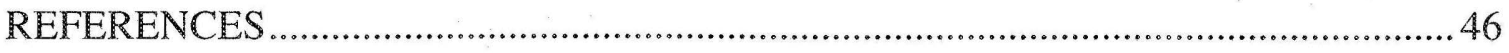

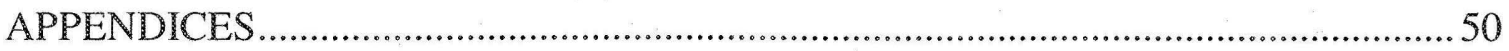





\section{INTRODUCTION}

\section{The Social Problem}

Muslim women in Canada are often viewed through the lens of Orientalist stereotypes. Edward Said created the concept of Orientalism, which refers to the conventional Western popular view that the Muslim civilization is entirely different from the western world, and it is bound by fanatical and barbaric beliefs that prevent it from becoming progressive and civilized (Said, 1979 cited in Bullock and Jafri, 2000).

A study conducted by Sajidah Kutty on the images of Muslim women in Western cultures found that the Western culture ascribes three identities to Muslim women. The first image portrays them as the sensuous belly dancer; the second as the oppressed the hijab wearer and finally the militant woman often portrayed as wearing the hijab with a gun (Kutty, 1997 cited in Bullock and Jafri, 2000). These images coincide with the general Western views about Islam being a exotic, primitive and uncivilized religion (Said, 1979 cited in Bullock and Jafri, 2000).

The view of the veiled Muslim woman as oppressed overlooks the complex social phenomena underlying decisions to adopt the hijab and the different meanings it has for different Muslim women. This view of Muslim women essentializes them and may create misconceptions in the Western societies about Muslim women and Islam in general (Bullock and Jafri, 2000). It may also lead to negative behaviours towards them. This becomes a social problem as Muslim women and girls who chose to wear the hijab may become the target of negative attention.

The Human Rights and Equal Opportunity Commission (2004) reported that in Australia cases of harassment of Muslim women wearing the hijab has increased post September 11, 2001. Despite this, the hijab has become much more common and many 
young women who decide to wear the hijab are first generation the hijabis, i.e. their mothers do not wear it and they may be facing opposition from their families for adopting the hijab (Hussein, 2007).

Why is it important to address this problem?

In 1989, three Muslim girls were denied entry in a school in Creil, France, as they wore the hijabs or headscarves. The hijab was viewed as a threat to the secularity of France. In 2004 a law was passed in France banning all conspicuous forms of religious dressing in schools. The argument for the ban was that obvious religious symbols were a hindrance to equality (Thomas, 2005; Zine, 2006). Similar issues concerning wearing the headscarf in schools have been found in Turkey, UK, Netherlands and Belgium (Smith, 2007; Shadid \& Koningsveld, 2005). In Canada, in 1994, a 12 year old girl was expelled from her school in Quebec as she refused to remove her hijab in the school. The teacher federation in Quebec supported the ban by voting in favour of keeping the hijab out of the schools (Zine, 2006).

The ban on wearing the headscarves in schools violates a person's right to religion and its expression. Article 18 of the UDHR, referring to the right to freedom of thought and religion, states that everyone has the right "...to manifest his religion or beliefs in teaching, practice, worship and observance" (Article 18, Universal Declaration of Human Rights). Another article referring to the right to education states that “...[Education] shall promote understanding, tolerance and friendship among all nations, racial or religious groups..." (Article 26, Universal Declaration of Human Rights).

In the light of the above mentioned human rights it is clear that such bans are violating the rights of girls who want to wear the hijab. They are being discriminated 
against due to the way they dress and their right to religious expression is denied. While it is important to acknowledge that there may be girls who are forced to wear the hijab, we cannot ignore the fact that there are girls who wear the hijab by their own free will. The problem is that we do not know why some girls choose to wear the hijab in families, communities and countries where they are not required to do so (Gereluk, 2005). This lack of knowledge results in perpetuation of incorrect assumptions and stereotypes.

Within the North American public schools case studies of Muslim girls wearing the hijab have found that their teachers often viewed them as oppressed and Islam was seen as a religion that discourages education for women. Further, these ideas resulted in low teacher expectation and resulted in girls opting for lower non-academic streams (Zine, 2006). Such negative attitude and misconceptions mostly affect young school age girls, who may be forced to remove the hijab, which for some is an important marker of their identity. Thus it is essential to understand their point of view about the hijab and the reasons why they wear it and their experiences of wearing the hijab. 


\section{LITERATURE REVIEW}

Canadian society is becoming increasingly diverse in terms of culture and religion. Immigrants from all over the world come to Canada for various reasons. The census enumerated $6,186,950$ foreign-born in Canada in 2006 . They represented virtually one in five $(19.8 \%)$ of the total population. The number of the foreign-born in Canada has nearly tripled during the past 75 years. The census estimated as many as $1,110,000$ newcomers arrived in the country between January 1, 2001 and May 16, 2006 (Census, 2006).

According to the Council on Foreign Relations (2006) there are 750,000 Muslims living in Canada. The population of Muslim immigrants has increased by almost 170,000 since 2001. Approximately $90 \%$ of the Muslim immigrants originate from South Asia and Arab countries. These immigrants bring along with them a rich cultural heritage and different religious beliefs. According to some researchers the importance of religious identities increases for these immigrants after immigration, as it plays a vital role in preserving their cultural identities (Cadge \& Ecklund, 2007). "Identity is generally used to define and describe an individual's sense of self, group affiliations; structural positions, and ascribed and achieved statuses. "Identity results from internal subjective perceptions, self-reflection, and external characterizations" (Peek, 2005, p. 216). The way immigrant groups focus on and integrate their religious and ethnic identities puts them in a unique position. The process of immigration brings the immigrant in a new country which may result in alienation and confusion. In order to adjust to this new situation and feel at home, immigrants take refuge in religion. They build religious institutions and places of worship to make their transition into the new country easier. Religion may take on greater importance for an immigrant in creating self identity and group affiliations than in their 
home countries where the religion may have been taken for granted, especially if these immigrants come from a country where they were a part of religious majority and after immigration become the religious minority in their new country (as in the case of Israeli Jews or Pakistani Muslims in the US) (Smith 1978, cited in Peek, 2005).

Religion is also used to maintain personal and social distinctiveness in the multicultural American context. Immigrants are becoming more aware of their traditions and make efforts to pass on those beliefs, values and behaviours to their children. In this sense, religious practices, the way of dressing and religious institutes and organizations help in promoting individual self awareness and identity and build strong group affiliations (Peek, 2005).

In a survey conducted by The Fourth National Survey of Ethnic Minorities (FNSEM) in 1993/94 in the UK by the Policy Studies Institute, it was found that the time spent in UK had minimal effect on the assimilation of Muslim immigrants. While higher education, high income job and living in neighbourhoods with low unemployment rate weakened the attachment of Non Muslims with their own cultures, it seemed to have reinforced religious identity of Muslims (Bisin et al, 2007).

Immigrant children encounter Western cultures upon entering schools. They are caught in the midst of maintaining a balance between their home culture and the cultures of their schools. Many a times there is a conflict between the two. Many young Muslim girls wear the hijabs or head scarves to schools. A lack of awareness among the teachers and school authorities regarding the reasons for and importance of this kind of dress can create tensions between parents and teachers at the cost of the child. Thus it is crucial to understand what the hijab is and why some girls wear it. 
Dress codes may serve critical social, cultural and political functions and act as an instrument of "non-verbal ideological communication" (Hoodfar, 2003, cited in Zine, 2006, p. 242). In this sense Islamic dress can be seen as an important means of communicating religious and social values (Clarke, 2003 in Zine 2006). The Muslim veil has been one of the most controversial forms of dress which evokes varied responses from different people. Different women in different time and space have various reasons for wearing it (Zine, 2006). The hijab worn by many Muslim women makes a strong statement about their awareness of their individual and religious identity (Shmidt, 2004). After the unfortunate events of September 11, there seems to be an increasing feeling amongst Muslim women to distinguish themselves in the West and reaffirm their Muslim identities. They do this by adopting traditional clothing, like the hijab, that makes them visible as Muslims (Ibrahim 1999 cited in Ruby, 2006). The purpose of choosing to wear the hijab is not only to dress in an Islamic way but it is used as a marker of Muslim identity. The hijab has, in this sense, become a symbol of the Muslim community. By choosing to wear the hijab women subscribe to the attitudes, values and beliefs of Islam and are linked to the larger Muslim community (Daly, 1999; Ruby, 2006)

\section{Religious meaning of Hijab}

In order to understand what the hijab is it is critical to refer to the Quran, which is believed by Muslims as the actual word of the God recorded by Prophet Muhammed (PBUH). The second important text referred to by Muslims for understanding Islam are the hadiths. These are records of Prophet Muhammed's (PBUH) sayings and practices in accordance with the Quran (Read \& Bartkowski, 2000). According to the Quran Muslim

men and women are required to dress modestly and cover their bodies appropriately. The 
Quranic verses, translated by Ali. A Yusuf as cited in Ruby (2006) that guides women's dress codes are:

1. And say to the believing women that they should lower their gaze and guard their modesty; that they should not display their beauty and ornaments except what (must ordinarily) appear thereof; that they should draw their veils over their bosoms and not display their beauty. . . And that they should not strike their feet in order to draw attention to their hidden ornaments. (24: 31$)$

2. Prophet! Tell thy wives and daughters, and the believing women, that they should cast their outer garments over their persons (when abroad): this is most convenient, that they should be known (as such) and not molested. And God is oft forgiving, most merciful. (33:59)

In the first verse mentioned above, the word khimar is used in the original Arabic version with reference to women's clothing. Khimar was a garment worn in pre-Islamic times which was let down loosely over the back of wearer and left their breasts exposed. The word khimar is used in the Quran to indicate that women's breast should be covered. Some scholars view the verses related here as a corrective to the pre-Islamic dress code and as a means to signify Muslim identity (Abou El Fadl, 2001; Hajjaji-Jarrah, 2003 in Zine, 2006). The second verse uses the word jilbab in Arabic, which means an outer garment covering the entire body or the neck and the bosom (Ruby, 2006).

The hadith literature related to dress includes only one report referring to women's clothing. According to this hadith, the Prophet Muhammed (PBUH) stated that at the age of puberty, women should cover all but their hands and face. However the authenticity of this hadith is in question (Clarke 2003, cited in Zine 2006). Some scholars assert that during the $7^{\text {th }}$ century the hijab became a visible marker of Muslim women so that they 
could be identified as Muslim, be considered under the protection of the Muslims and can thus avoid any kind of harassment (Abou El Fadl, 2001; Hajjaji Jarrah, 2003; Roald, 2001 in Zine, 2006).

According to some religious scholars a woman is required to wear the hijab to cover her ears, neck and hair. This view reflects the requirements of modesty in clothing by the Quran, thus it is logical that a substantial number of women wear the headscarf or the hijab believing that it is mandated by the Quran. From this perspective, a ban on wearing the hijab may infringe upon a Muslim woman's right to freedom of religion as it obstructs her from following what is prescribed in her religion. On the contrary, some scholars propose that the Quran does not clearly direct a woman to wear the hijab, but rather refers to a general need for modesty. It requires a believing woman to dress modestly to prevent harassment by men. However, the decision about whether an action is in accordance with a religious dictate lies with the individual. Thus if a Muslim woman believes that by wearing the hijab she is fulfilling her religious duties, restraining her from wearing the hijab violates her right to freedom of religion (Ziegler, 2007)

\section{Defining the Hijab}

According to Ruby (2006) it is essential to differentiate between the terms the hijab and veil. Veil and the hijab are not equivalent and the Encyclopedia of Islam identifies over 100 terms as pieces of clothing, many of which, such as 'burqa', 'abayah', 'jilbab', niqab, and izar, are used for the covering of a female body (El Guindi 1999, in Ruby, 2006). This implies that the word hijab can have multiple meanings. For example, a woman wearing a niqab in Saudi considers it the hijab whereas a Canadian Muslim woman may adopt a headscarf and call it the hijab. The Quran, which is the religious text 
of the Muslims, has not used the hijab in referring to Muslim woman's clothing. In the Quran the word hijab is used to refer to something that protects but also something that can obstruct (Ruby, 2006). Due to the complexity of interpretation, there is a difference of opinion amongst the scholars about how much of the body should be covered (Zine, 2006). For this paper I will use the word The hijab identified as the headscarf popularly worn by many Muslim women in North America.

\section{Perceptions of the Hijab in Western Society}

The hijab has been viewed by the Western cultures as-symbols of oppression of women in the Muslim world (Cloud, 2004 in Droogsma, 2007). The media plays a major role in promoting stereotypes about Muslim women in North America. Images of covered women have often been used to illustrate the "backwardness" of Muslims and the subordination of women in Muslim societies (El Guindi, 1999; Steet, 2000 in Droogsma 2007). According to Ruby (2006), many studies have shown that the image of the Muslim woman portrayed by the dominant North American media is that of an "oppressed and passive hijab wearer"(p. 62). The hijab has come to be seen as a symbol of Muslim world and is associated with "religious fundamentalism and extremism" (Zine, 2006, p.242). Due to the tragic events of September 2001, misunderstanding about the Muslim community has increased and little has been done to focus on the positive aspects of Islam (Ahmed \& Szapara, 2003).

Most of the media portrayals of the hijab are due to the power dynamics of European colonialism. The hijab represented a clear evidence of inferiority of the colonized and eliminating it would help make the Muslim societies modern (Thomas, 2005). Atasoy (2006) asserts that the hijab or veil as a symbol of woman's oppression 
was developed when European powers colonized Muslim societies. During this period, the beliefs and practices of Islam were viewed as a part of a regressive culture. On the other hand the European culture, which promoted personal freedom, was seen as liberating. Thus in order to liberate themselves the Muslim woman must defy the Islamic norms (Atasoy, 2006). In the view of Muslim women as oppressed and in need of rescue, Ruby (2005) cites the example of the Taliban forcing the wearing of burqa in Afghanistan. She points out that the tradition of burqa was not created by the Taliban. In fact it was there even before them. And even after the Taliban regime ended women still wear the burqa. This shows that many women choose to cover themselves according to Islamic principles and do not necessarily see it as oppressive. There are many reasons why Muslim women chose to wear the hijab besides its religious significance, especially in non-Muslim societies. The hijab can become a means of asserting one's own identity as a Muslim (Thomas, 2005). How we dress is crucial in conveying one's identity to others. The male dominated cultural norms of the Western society often determine the "acceptable" fashion for women which may include clothing which are tight and may reveal the shape of the body (Borisoff \& Merrill, 2003 in Droogsma, 2007). On the contrary the hijab usually tends to cover most of the women's body. Many studies (e.g. Ruby, 2006; Atasoy, 2006) have found that many Muslim women feel that the hijab has been liberating experience for them and that they don't have to confirm to the western rules of how a women should dress and are able to avoid unnecessary sexual attention.

\section{Hijab and Education}

According to Nowak (2001, in Smith, 2007) an in-depth study of international provisions for education concluded that education has four purposes, 
1. to help human beings develop their personality and dignity

2. to capacitate human beings to actively participate in a free society of mutual tolerance and respect for other civilizations, cultures and religion,

3. to promote respect for one's parents, the national values of one's countries and the natural environment and,

4. To develop respect for human rights, fundamental freedoms and the maintenance of peace.

In Western societies, Muslim girls who choose to wear the hijab in schools have been victims of ridicule and exclusion (Hamdani, 2004, cited in Zine 2006). The hijab has been surrounded by controversies in many parts of the world. In March 2004 France passed a law which restricted students from wearing any form of obvious religious symbol to schools (Smith, 2007; Zine 2006; Thomas, 2005). The ban on wearing headscarves in Turkey in the name of secularism was accepted by the European Court of Human Rights. In the UK a Muslim girl was not allowed to wear jilbab as a part of her school uniform (Smith, 2007).some people believe that the ostracization of the hijabwearing women has increased because of Islmaophobia. Islamophobia can be defined as "a fear or hatred of Islam and its adherents that translates into individual, ideological and systemic forms of oppression and discrimination" (Zine, 2003 cited in Zine, 2006, p. 239). Girls who dress according to the Islamic code of dressing that prominently categorizes them as Muslims face Islamophobia. Zine (2006) calls this "Gendered Islamophobia" which can be understood as discrimination based on the negative stereotypes of Muslim women (p. 240). Historically American public schools have echoed and preserved the values and traditions of the white Anglo-Saxon dominant groups. However, the population of North America is rapidly changing and becoming 
more and more culturally and religiously diverse. It is therefore imperative that schools make accommodations to include such a diverse population in the classrooms (Ahmed \& Szpara, 2003).

Teachers bring to class their own beliefs and values based on their experience of cultures different from their own. Similarly students bring their own beliefs and values to the class. These may be conflicting at times due to the teacher's lack of experience with different cultures (Chan, 2006). Nevertheless, teachers play an important role in helping students understand diversity and develop tolerance towards it (Pang, 2005 cited in Subedi, 2006).

A study conducted by Hoot, Szecsi and Moosa (2003) designed to understand teachers' knowledge about Islam revealed that almost one-third of the participants held negative connotations with the word "Islam." Historically, the aim of education has been to liberate all students, including women. Veiling, which has been seen as oppressive of women, could not be accepted from this view. As a result in some French schools the hijab-wearing students have been expelled from their schools. However, some French thinkers argue that expelling girls is not the solution. It may lead them to private schools which can further isolate them from the main society (Weil, 2004, in Thomas, 2005). While bans on wearing the hijab were thought of liberating women, it is interesting to note that the women were not asked what they felt about the hijab (Lenke, 2000 in Zine, 2006; Wieviorka, 2004 in Thomas, 2005). The next section explores the views that Muslim women hold about veiling. 
"The white, Eurocentric, secular cultural codes of Canadian society are the standard of measure against which all other identities are judged and positioned and within which all other identities must be disciplined into conformity or face exclusion" (Henry \& Tator, 2005 in Zine, 2006, p. 246).

The above view enforces the exclusion of girls who do not adhere to the code of dress prescribed by the dominant society. In her study on Muslim girls in Islamic schools in Canada, Zine (2006) found that although the schools were segregated on the basis of gender these girls reported feeling more accepted in their schools as compared to public schools they had attended in the past. Girls who adopted the hijab for religious reasons also found it helpful in avoiding undue male attention (Zine, 2006).

Anecdotal evidence suggests that more and more women are wearing the hijab an important part of their identity. There are many reasons why women wear the hijab. Many women see the hijab as empowering. It gives them a unique identity and they feel more connected with the larger Muslim community (Ruby, 2006). Chan (2006) observed that many South Asian women wear it with pride and feel liberated by it. Atasoy (2006) claims that more and more young girls and highly educated women in Egypt are embracing the hijab to show others that it does not stop them from participating in public life and at the same time maintains their dignity. It is the North American portrayal of women that represents the hijab as oppressive and asserts that it is imposed upon Muslim women (Ruby, 2006).

On the one hand, many who support the ban on the hijab argue that this ban is aimed to liberate Muslim women from oppression, helping them to achieve their fundamental right of freedom of expression and equality with men. On the other hand, 
those who oppose the ban argue that the ban infringes upon the basic rights of minority religious and cultural communities to express their self identity, which is their fundamental human right. However all these debates over fundamental rights often seem to ignore the specific context of a Muslim woman's decision to wear the hijab. Different woman in different social contexts may have different reasons for wearing it. The hijab may be forced upon them or it might be adopted by choice. According to some Muslim feminist wearing a hijab may make the woman feel liberated and allow her to move freely in public space (Freedman, 2007).

In a study carried out by Droogsma (2007) the author found that the hijab serves six major purposes according to the women interviewed:

1. Assert a Muslim identity: The hijab is a visible sign of being a Muslim. It asserts one's membership in the larger Muslim community. Despite some negative experiences most women wear the hijab with pride. Many women in this study, especially new converts to Islam found it an important marker of identification with commitment to Islam.

2. Regulates behaviour: Many women in the study reported that the hijab helps them to behave modestly in society and keeps a check on their behavior. This is important in term of their interaction with men.

3. Restricts the view of women as sexual objects: Many women felt empowered by the hijab as it helps them ward off unwanted sexual attention by men.

4. Increases respect: The hijab does provide respect to women. However women in hijab were targets of harassment after September 9/11.

5. Secures close relations: Women in this study felt that only their husbands had the right to see their beauty and the hijab helps them protect and preserve it for them. 
6. Is liberating: Four women in the study reported that the hijab provided them with the freedom from the pressure to conform to the dominant society's codes of dress. According to them the American women are exploited by the standards of fashion. The hijab is viewed as liberating them from this exploitation.

Clothing and appearance are deeply rooted within any social and cultural context (Kaiser, 1997 in Droogsma 2007). American Muslim women find themselves in a struggle to be a part of the American culture and conform to the fashion norms as well as the American Muslim community and dress in ways considered appropriate in Islam. This position influences their choice of clothing and also the choice to adopt the hijab (Droogsma, 2007).

The discourse around policies and legislations banning the hijab claims to protect the rights of Muslim woman from the patriarchal nature of Islam which requires them to cover their heads, thus promoting gender equality. However this notion can be contested that the policy of banning the hijab has, in the name of supposedly universal but arguably Eurocentric conception of woman's rights, done more harm than good in terms of letting these women exercise their rights, and has further excluded then from the European societies (Freedman, 2007). In order to understand the lives of these women and the negotiations and choices they make it is important to listen to their voices.

\section{The Study}

This review of literature has highlighted the fact that the hijab is viewed as a mark of women's oppression in Western society. While most of the studies found in the literature focus on women's view of the hijab, Zine (2006) conducted a study on young, school age girls wearing the hijab in a Canadian Islamic school. She found that all the girls included 
in the study had voluntarily adopted the hijab and as a result had experienced racism outside the school. Although they were segregated by gender in their Islamic school, they reported feeling even more segregated in the public schools they had previously attended, due to lack of understanding of their faith.

Traditionally, Muslim girls start wearing the hijab when they reach puberty, usually around the age of $11-13$. It is therefore important to study what they think about wearing the hijab when they begin to do so. This is also the age when girls typically become more susceptible to social pressures, particularly those that are related to their sexual identity. Their self-images are influenced more strongly by their peers, sometimes resulting in conflicts between them and their families. It is therefore important to ask the following questions:

1. Why do young Muslim girls wear the hijab?

2. What have been their experiences related to wearing the hijab within the public schools in Canada? 


\section{METHODOLOGY}

"The standpoint of women situates the inquirer in the site of her bodily existence and in the local actualities of her working world... Those who undertake inquiry from this standpoint begins always from the women's experiences as it is for women. We are the authoritative speakers of our experiences." (Smith, 1990, cited in Garner, 2000, p.484).

According to the feminist standpoint theory one's experiences of the world, the self and consequently one's knowledge are determined by one's social position (Wood, 1994, in Droogsma, 2007). The standpoint theory presupposes that marginalized groups are controlled by certain dominant social groups that control the structure and cultural expectations of the society (Dougherty, 2001, p. 373, in Droogsma 2007). Further, this theory highlights the importance of appreciating the differences in the experiences of women. It recognizes that marginalized women may experience further oppression and that their standpoints are not necessarily consistent with those of women who belong to the dominant socio-cultural groups. Muslim women's social position in the American society can be studied using the standpoint theory as it provides an opportunity to analyse what these women have to say about the hijab (Droogsma, 2007).

\section{Scope}

This study attempted to understand the reasons for and experiences of Muslim school age girls wearing hijab in the Canadian public school system. The age range of the participating girls was between 11-13 years. I have chosen to focus on this age as most of the studies on hijab have focussed on adult women and their views. There is very little attempt made to understand what girls of this age have to say. Also, these girls are the ones who may have to face the negative attitudes of teachers and peers in schools. Thus it 
is very important to understand how they view their situation and what determines their choices.

\section{Approach}

The approach used for this study was qualitative. The purpose of this study was to understand the perspectives of young Muslim girls, not to measure the frequency of their opinions. Qualitative research involves studying in detail, the cases or event that spring form our everyday lives and provide authentic analysis that are relevant to specific context (Newman, 2006). The main purpose of this particular study was to understand a social phenomena and its relevance in a particular context i.e. wearing of the hijab by young Muslim girls in Canadian public schools.

\section{Strategy}

The strategy I used for this study was grounded theory, which is based primarily on inductive reasoning (Neuman, 2006, p.60). Grounded theory is developed by systematically gathering and analyzing the data. In this process the researcher begins the research process without any preconceived theory in mind. The theory emerges during the research process. The advantage of grounded theory is that since it is heavily based on the data, it provides new insights and increases the researcher's understating of the phenomenon being studied (Strauss \& Corbin, 1998).

\section{Setting and sample}

The setting of the study was a meeting room in the building in which I live. One of the participants lives in the same building, another one in the next building. Two other participants live nearby and were accompanied by their mothers to the site where the girls 
were interviewed. The setting was decided after consulting with the parents and the participants.

The sample included four young Muslim, hijab wearing girls attending public school in Toronto. The participants were limited to four due to time constraints. The age range of these girls was 11-13 years. This age was selected as there is lack of literature related to this age group. As noted above, Muslim girls are often expected to begin wearing the hijab at the onset of puberty, which typically falls within this age. At this age, girls often become more aware of their sexual and group identity, and become more vulnerable to conflicts that may arise from different pressure groups, such as peers and family members.

The sampling method used was snowball sampling. In this method the researcher identifies subjects with characteristics relevant to the study and then they are asked to suggest names of other subjects with same characteristics (Berg, 2001. p. 33) The names of the participants have been changed to protect their privacy and each participant is given a pseudonym. All participants attend the same Canadian public school.

\section{Researcher Self Disclosure}

I have been wearing the hijab or the headscarf for the past five years and personally it has been a liberating experience for me. I have come across people who hold certain misconceptions about the hijab. I acknowledge that due to my personal beliefs and experiences I may be inclined towards highlighting the positive experiences of wearing the hijab and ignoring the negative ones. However, recognizing this tendency also alerted me to this possibility and hopefully promoted greater self-reflection in my analysis. 
It was also my concern is that my wearing the hijab might influence the participants' responses. I addressed this issue by explaining to the participants that people have different views about the hijab. I also tried to address this issue by formulating questions that are open ended and do not threaten the participants' self image.

\section{Data Collection}

I began the data collection with a focus group discussion to identify common perceptions, issues and experiences. A focus group is defined as a "discussion involving small number of participants, led by a moderator, which seeks to gain an insight into the participants' experiences, attitudes and/or perceptions." (Hennessey \& Heary, p.236, in Greene \& Hogan, 2005). The advantage of this tool is that it evokes responses that may not be elicited with individual interviews alone, as the participants feel more secure in sharing their opinions in a peer group. The disadvantage of a focus group is that participants' responses can be influenced by other group members and they may respond in a particular way just to be a part of the group (Greene \& Hogan, 2005, p.237 \& 239).

In an individual interview the researcher can ask questions that may be unstructured, open-ended, informal and in-depth. The researcher seeks to gain insight into the participant's perspectives and experiences (Neuman, 2006, p. 406-407). Conducting individual interviews after the focus group session gave me the chance to explore topics discussed in the focus group, asking the participants to elaborate, illustrate or challenge what they or others had said during the focus group discussion, based on their own views and experiences. I found the focus group very helpful in generating a dynamic discussion around the hijab. The participants also noted that they felt good knowing that other people have had similar experiences and that they are not alone. All the girls except one 
were eager to share their experiences. One of the reasons I chose to interview each participant after the focus group was that one or more participant might be hesitant to express her views during the focus group. As anticipated, the interview situation proved to be more comfortable for this participant.

\section{Data Organizing}

The focus group sessions and personal interviews were audio recorded and fully transcribed. They were kept confidential and only the researcher and the supervisor had access to it. The electronic copy was protected by a password known only to me. Hard copies of the data were also kept in a safe place accessible only to me and my supervisor. The data will be destroyed two years after the completion of the study.

\section{Data Analysis and Interpretation}

The organization of the data into themes and concepts begins with coding. As described by Miles and Huberman (1994, cited in Neuman, 2006, p.460); "Codes are tags or labels for assigning units of meaning to the descriptive or inferential information compiled during a study...". Coding helps to manage and categorize the data.

Data for this study were analysed by starting with open coding. During this process patterns in the data were identified and initial codes were assigned to the data in order to compress the data into categories.. This was followed by axial coding. Here the already organized initial sets of codes were further analysed. The focus here was on codes rather than the data itself. In axial coding the researcher tries to determine "...causes and consequences, conditions and interactions, strategies and processes..."

within the data and identify categories that are similar. The final step was selective coding. This involves scanning of data to look for cases that exemplify the themes and 
make comparisons and contrasts (Neuman, 2006; p. 460-464) These themes and concepts are eventually linked to each other to formulate a theory (Neuman, 2006; p. 460), which is what I tried to do for the final analysis. 


\section{FINDINGS}

\section{The Participants}

Aleena is now 13 and started wearing the hijab when she was around 11 years old. Her parents are from Pakistan but she was born in Canada. Her mother also wears a hijab. She started wearing the hijab when she saw one of her cousins wear it and she thought it was "cool". Her parents were extremely supportive and praised her (saying that she looked good in a hijab) and encouraged her to wear it to school. She says her parents never forced her to wear the hijab. Gradually she realized that Islam requires women to wear the hijab and she understood the true meaning of the hijab..."it became important to me and I understood, like, why I was wearing it". She says it makes her feel secure and better about herself.

An interesting incident at school reaffirmed her faith in the hijab. She says she used to be bullied in school. But since she started wearing the hijab, the bullying stopped. She still does not know what the reason was, but she feels it was due to her the hijab. She thinks probably people started respecting her more as an individual and her the hijab..."I started wearing the hijab and that just represented my religion so they started to respect me more".

She feels respected and protected when she wears the hijab. She says she does not need to worry about how she looks. Her family and friends are very supportive and encouraging. Sometimes in school her friends tell her to take it off but she does not. When asked has she ever considered not wearing the hijab she says, "It's basically like a part of your body. Like if it was taken off I would feel like one part of me has gone". 
She feels that by choosing to wear the hijab she has made her parents proud and that makes her feel good about herself. She also feels that by wearing the hijab she is fulfilling her religious duties..."... it feels good to know that I have not let my God down. I am actually trying to prove myself worthy of being Muslim...". Despite some negative experiences she says that she has never thought of giving up the hijab.

Ishrat is Aleena's sister and is now 12 years old. She started wearing the hijab when she was 9 years old. Her mother wears the hijab and as a child she would copy her mother by wearing the hijab at home. Her parents encouraged her to wear the hijab more often and in school. She says her parents never forced her to wear the hijab and it was entirely her decision to wear it every day. She says the hijab represents Islam and protects her from evil. Also, she believes the hijab frees her from worrying about her looks. Her friend and family generally support her for wearing the hijab. Sometimes in school some of her friends urge her to take it off but she refuses. "It's a part of who I am so I just can't take it off", says Ishrat. When asked has she ever considered not wearing the hijab she says, just initially when she had started wearing it but she got used to it. Now, she says, she is very comfortable and happy to wear the hijab, "...I feel proud that I am unique and it shows who I am, basically that I am a Muslim".

Ayesha is 13 years old and is in grade 8 . She stared wearing the hijab four months back. Her parents are from Pakistan and she was born in Canada. Her mother does not wear the hijab; however she does cover her head with a long shawl. Ayesha started wearing the hijab six months ago. Her mother is always said that she will never force her daughter to wear the hijab but will also not stop her if she chooses to wear it. Now that Ayesha has chosen to wear the hijab her mother feels proud of her and buys her hijabs that match with her dresses. The reason Ayesha started wearing the hijab is the influence 
of her friends. She said, "... whenever I looked at other Muslim girls, I saw them wearing the hijab and I felt like a bad person...". She says that knowing that Islam requires girls to cover, she felt guilty that she was not wearing the hijab. Her friends encouraged her to wear the hijab and her family supported her. Also she felt that wearing the hijab is a part of her culture and she should show it in public.

Ayesha says she is very happy with her decision and her religion gives her the strength to stick to it..."...I feel kind of proud of myself that I should the hijab because it makes me feel good". She did think about taking it off for good during the initial period due to some of her friends' reactions but her mom supported her and explained to her why girls are required to wear the hijab but still left the decision on Ayesha. She then decided to keep wearing the hijab. She said. "... my religion kept me going". At school she had some negative experiences during participating in sports activities. Some boys told her that Muslim girls cannot play basketball because the hijab may obstruct the game. However like Aleena she chooses to ignore the negative experiences and does not let them come in her way in anyway.

Sumaiya is 12 years old and is in grade 7 . She started wearing the hijab when she was in grade 5. Her parents are from Somalia and she was born in Canada. Her mother wears the hijab. She started wearing the hijab when she was 10 years old. She says it wasn't a big change for her as everyone in her family wears the hijab so she was well prepared for it. She said she wasn't forced to wear the hijab. It was her choice because she feels it is her religious duty to wear the hijab and by fulfilling her religious duties she will be granted 'jannah' (paradise) upon death. Sumaiya's reasons for wearing the hijab were more spiritual. She said the hijab protects her from 'shaytan' (the devil) and helps her to take right decisions when she is in a test (for example, when the devil makes her 
feel lazy to pray, the hijab reminds her of her religious duties). She says," I feel pretty good because when I am in tests and everything I know that the hijab is there". Her family and friends are very supportive. She always tries to match her accessories and shoes with her the hijab. Outside of school she also wears the 'abaya' (long, loose cloak). However in school she only wears the hijab due to uniform restrictions. When asked has she ever considered giving up the hijab she said only when she initially stared wearing it..." It was itchy and I wanted to take it off". But now she says it feels like as if the hijab is attached to her, "...it's another part of my body on my head". She says she will never give up her the hijab as with the hijab on she does not worry about her looks and also because she is able to follow her religion. According to her, "... I realize that one day everybody's going to die; they have to reach for 'jannah' so I believe that life is a test and that when you die Allah's going to test you again. So either you go to hell or paradise". 


\section{REASONS FOR WEARING THE HIJAB: RELIGION, CULTURE AND SELF IDENTITY}

The aim of this research was to find out why young Muslim girls wear the hijab. I wanted to know whether they wear the hijab just because they are told to do so by their parents or do they really understand the true meaning and purpose of the hijab. In the literature review we have observed that there is a conflict about whether or not the hijab is mandated by the Quran. According to the Quran Muslim men and women are required to dress modestly and cover their bodies appropriately. There is a difference of opinion amongst scholars regarding a Muslim woman's dressing. Some religious scholars believe that a woman is required to wear the hijab to cover her ears, neck and hair. This view reflects the requirements of modesty in clothing by the Quran, thus it is logical that a significant number of women wear the headscarf or the hijab believing that it is mandated by the Quran. On the contrary, some scholars propose that the Quran does not clearly direct a woman to wear the hijab, but rather refers to a general need for modesty. It requires a believing woman to protect her privacy to prevent harassment by men. However, the decision whether an action is in accordance with a religious dictate, lies with the individual (Ziegler, 2007).

When I asked the girls why they wear the hijab, all of them gave religion as their primary reason for wearing the hijab. They said that Islam requires them to do so. According to these girls it protects them from shaytan (devil) and prevents them from doing anything wrong. The following quotes illustrate their opinions:

Aleena: it protects us, basically it's our protection or our cover and it protects us from the evil eye and it represents our true meaning of Islam and a religion. It symbolizes our character and our religion basically. 
Sumaiya: I think people wear the hijab because the meaning of the hijab is to cover, to cover themselves from shaytan and boys and cover yourself from like Allah think that you're a very worthy servant for him...

Ishrat: ... it covers us to protect us from evil and shaytan...

In the above sense the hijab is considered as a divine order and by following it the girls feel they are fulfilling their religious duties. They see the hijab as a good thing for themselves. All the participants said it makes them feel good about themselves and they feel better Muslims by wearing the hijab.

Another reason why they wear the hijab is that wearing the hijab is considered a part of Islamic culture. The girls consider the hijab as a symbol of Islam and Islamic culture and they show their affiliation to this culture by wearing the hijab in public.

Ishrat: I think Muslin girls wear the hijab because it represents Islam and for people to know that you're from the Islamic culture.

Aleena: it shows you know your culture, where you're from and it's just like your individuality as like a person, as a Muslim.

Ayesha: we are here to show our culture and that's our religion.

Interestingly, religion and culture were used interchangeable throughout the interviews and the focus group. This may be because Islam is not only considered a religion but a way of life by its followers. Islam not only teaches its followers their religious duties but also provides them with guidance about their day to day affairs in accordance with the Islamic principles. Thus the girls said a number of times that they wear the hijab because of their religion and also because they want to identify with their Muslim culture. In this sense Islamic dress can be seen as an important means of communicating religious and social values. Dress codes may serve critical social, cultural 
and political functions and act as an instrument of 'non-verbal ideological communication' (Hoodfar, 2003 and Clarke, 2003 in Zine 2006).

The literature shows that the importance of religious identities increases for immigrants after immigration, as it plays a vital role in preserving their cultural identities (Cadge \& Ecklund, 2007). Accordingly, religious practices, the way of dressing and religious institutes and organizations help in promoting individual self awareness and identity and build strong group affiliations (Williams 1988, in Peek, 2005.). The hijab worn by many Muslim women makes a strong statement about their awareness of their individual and religious group identity (Shmidt, 2004). There seems to be an increasing feeling amongst Muslim women to distinguish themselves from the West and reaffirm their Muslim identities. They do this by adopting traditional clothing, like the hijab, that makes them visible as Muslims (Ibrahim 1999 in Ruby, 2006). The purpose of choosing to wear the hijab is not only to dress in an Islamic way but it is adorned as a marker of Muslim identity (Daly, 1999; Read \& Bartkowski, 2000 in Ruby, 2006).

The girls strongly felt that the hijab has become an important part of their individual self identity. When asked whether they had ever considered giving up the hijab they said that the hijab is like a part of their body and they cannot imagine themselves without it anymore. They said their faith in their religion and parental support gave them the courage to go on with it. And now they truly understand the meaning and purpose of the hijab and they would never give it up. The following quotes illustrate this position:

Aleena: I love wearing the hijab. It's because it's part of me. I never really feel anything because it's just like...its like how would you feel if ...that you have two arms? It's basically like a part of your body... I mean it has become like who I am so without it would just be like empty, like you know you would feel like you lost a part of yourself. 
Sumaiya: I Yeah it's another part of my body on my head. It's pretty much attached to me. Wearing the hijab, it's like it's attached to me. Sometimes when I'm in the house I don't even take off my the hijab. I got to sleep in my the hijab.

Ishrat: And I always have to tell her that it's like one of my responsibilities. It's like why do you brush your teeth every morning. It's because you have to, it's part of who you are. My dad always has to remind me to take off my the hijab before I go to sleep.

Peek (2005), in her research on the process of religious identity formation in second generation Muslim Americans, proposed a three stage model of Muslim religious identity development. The first stage is of religion as ascribed identity, where the participants took their religious identity for granted especially during childhood when children follow their parents in performing rituals without really understanding them. The second stage is religion as chosen identity. Here her participants reported reflecting on and understanding their religious duties and then embracing a Muslim identity. The third stage, religion as declared identity developed after September 11 2001. Her participants felt that it was crucial to reinforce and proclaim their identities so that they can maintain a positive self perception and clear any misunderstanding $\mathrm{s}$ about their religion.

The girls in my research seem to go through similar stages. Initially when they started to wear the hijab it was more of following what their mothers did. Then they understood why they should wear the hijab and accepted it as a part of their identity. Lastly the fact that they wear the hijab as a way of showing their culture and explain to their friends why they wear it and what its benefits are coincides with Peek's declared religious identity. 


\section{CHOICE vs. SOCIALIZATION}

According to Arnett Jeffery Jensen (1995), "Socialization is the process by which people acquire the behaviors and beliefs of the social world--that is, the culture--in which they live. The three goals central to this process are: (a) impulse control, including the development of a conscience, (b) role preparation and performance, including occupational roles, gender roles, and roles in institutions such as marriage and parenthood, and (c) the cultivation of sources of meaning--that is, what is important, what is to be valued, what is to be lived for." (p. 617). Quoting Scarr (1993), Jenson (1995), asserts that the culture that we live in sets the boundaries on the growth of an individual and is the core of socialization. According to Jensen, children start learning these expectations in infancy and they remain with them throughout their life. Amongst the many sources of socialization I have chosen to focus on family, peers and media for my research as they were discussed in detail by the girls.

\section{Personal Choice and Family Expectations:}

Immigrant parents face the challenge of bringing up their children in a cultural environment which is different from the cultures in which they were born and raised. Parenting practices and parental expectation differ greatly when parents come from a culture different from their host country. This may create a sense of fear in parents that they may lose their children to the culture of the host country. As we have seen in the literature review religious identities become more important in immigrants after migration in an attempt to preserve and pass on their cultural values to their children.

The girls in this study asserted that the decision to wear the hijab was their own and they were not forced by their parents. In all four cases there was no parental pressure 
to wear the hijab. However, there was a lot of parental support for wearing it. In all four cases the parents praised and encouraged the girls once they started wearing the hijab. An important point to note here is that the values and practices of a family are a reflection of their cultural values that the parents want to transmit to their children. They are not created by the parents themselves; rather they are learnt by them as a part of their own socialization process (Jensen, 1995). The girls participating in this study were obviously encouraged by their parents to wear the hijab, but they also clearly believed that the decision to do so was their own:

Aleena: My parents said if you don't want to wear it, its okay... So it was never under any force or my parents said okay, wear it, you have to wear it.

Sumaiya: My mom never forced me, I just felt like it because I said I have a duty to wear this because I want to get granted paradise.

Ayesha: my mom, first she told me you should wear the hijab, but said I'm not going to force you. It's your choice. If you do want to wear it, it's good for your own. If you don't want to wear it it's your choice.

Ishrat: Yeah, like even my dad, he said that you're not forced to wear the hijab and he told me like what the reasons are and he started explaining how there is...it's a good thing to wear the hijab. It's not forced it's just a good thing.

According to Schmidt (2004), the concept of choice is influenced by Western discourses where the actions of human life are considerably individualized. Following aspects of one's traditions and lifestyle of one's' community is considered primitive, repressive and even undemocratic. To be able to make a choice is considered one's human right and "an aspect of high social status on local and global scenes" (p. 35). Young Muslims need to make a choice and justify it by stressing the significance of their culture. By stating that they choose to adopt a lifestyle in accordance with their religion 
and culture because it allows them to live a life they desire, they reduce the risk for any criticisms. The girls in this research also stressed on the fact that the decisions to wear the hijab were their choice. This focus on the choice emerges from the need to clear the general misconception that the hijab is forced upon them by their parents.

Another issue about choice is that parents might expect their daughters to choose to wear the hijab and the girls might chose to wear the hijab in order to please their parents. Also the age at which they 'choose' to wear the hijab, in most cases, is when the girls will be expected to wear the hijab by their religion and family members (Hussein, 2007). In a study conducted by Sheriff, Tirmazi \& Walsh, on immigrant South Asian Muslim mothers, they found that they all expected their daughters to practice Islam and appropriate behaviors such as modesty in clothing, respect for self and others through personal behaviors and relationships and discretion in decision that would reflect the family name through their behavior (p.202, in Lansford et al, 2007). These expectations are obviously likely to influence decisions made by their daughters.

Nevertheless, the girls in this study did not acknowledge any pressure from their parents to wear the hijab. Only in Ayesha's case she seems to have been pressured by her friends to wear the hijab. The other three girls initially wore the hijab to see if they were comfortable in it and did not wear it regularly for almost a year. It was only after fully understanding the meaning and benefits of the hijab did they start wearing it on everyday basis. Thus the data suggests that while the girls did recognize their parents' encouragement and support, they believed that the choice to wear the hijab was their own. 
In a study conducted by Zine (2000) examining the Muslim student subcultures in Ontario schools, she found that Muslim students experienced two kinds of peer pressures, both negative and positive. The positive peer pressure originated from the students' social networks which they were able to develop within the Muslim community, which provided support and provided guidance related to both religious and academic concerns. The negative peer pressure generated from both through non-Muslim students as well as Muslim students who had accepted the values of the popular culture, which pressured them to reject their religious practices and identity. The girls in my study faced both negative and positive peer pressure.

The practice of veiling is largely misunderstood and is seen as a symbol of women's inferiority to men. Most of the time it is considered as forced upon women and girls by their parents. The girls in the research faced similar stereotypes. They said that most of their friends understood but some still feel that it is forced. However since the school they attend has a multicultural population the hijab is not uncommon and so many students are used to seeing girls in the hijabs in their school. Most of the questions about the hijab come out of curiosity. Their friends keep asking them why they wear the hijab. The girls showed frustration over the fact that they had to give everyone an explanation as to why they wear the hijab.

Aleena: So I mean they would always ask me, like the first question that is actually annoying is why do you wear the hijab? Where do you...you know there's questions that arise immediately and there's no problem for that. I mean sometimes it's not meant in a negative way yet sometimes they are meant in a negative way. Like oh my god, why is she wearing that or you know why...oh I bet her parents forced her. And sometimes its not exactly like the matter of force or anything, it's a matter of religion, it's a matter of choice. And they believe that sometimes some of my friends they're like oh don't you want to show your hair, don't you want to do this? And you know, what's up why do you wear the hijab? 
And those questions in their own point, yeah they're curious, but I mean they come to the point where you ...you're like okay, oh my gosh, like seriously, can I not wear my the hijab in peace? But I mean I can understand why they would ask questions like that.

Ishrat: every year there's like new people and I always, every year I have new friends and there's one friend who came this year and she's new to the school and she's, everyday she's like why don't you take it off? Are you forced to wear it? Take it off; if you're not forced then take it off? Why are you wearing it? And I always have to tell her that it's like one of my responsibilities.

Ayesha: they kind of blame it on other friends that they said...this girl, she said, the other Musim, she forced me and she always told me that this other girl forced you so why are you going to wear it, it's your choice? I'm like yeah, it was my choice. So she still says that now. Take it off.

In Ayesha's case there seemed to be an indication of some peer pressure to wear the hijab (positive peer pressure). She said her Muslim friends encouraged her to wear the hijab and would tell her that being a Muslim she should wear the hijab. However she insisted that her decision to wear the hijab was not under any pressure and she was happy with her decision.

The girls also unanimously agreed that the hijab had given them the freedom from worrying about how they looked and how people looked at them in terms of physical beauty. Ishrat spoke about a girl in her class who kept touching her hair and worried about how it looks all the time. She said that she is glad she wears the hijab as with the hijab on she does not feel self conscious about her hair. The following quote provide examples of the girls' position on this:

Aleena: I feel respected and I feel like I can actually be myself and not have to worry about how I look, like how is my hair and you know. I feel good wearing it.

Sumaiya: Yeah, like l'm not the kind of girl who is always like touching your hair. I'm not conscious of my hair at all. 
Aleena: a lot of my friends they're like take it off, come on I want to see your hair. I mean you know, it's so... and sometimes like okay when I'm in the bathroom I'll be fixing my the hijab in the girl's bathroom so I have some privacy and my friends will see my hair and say oh my god your hair is so pretty and why don't you just show it and it's so like why don't you just take it off? Its okay, just take it off for one day, take it off...it's kind of what participant 4 said, it's like a routine for you. It's like why do you brush your teeth right. I mean it has become like who I am so without it would just be like empty,

Sumaiya: Yeah, sometimes because they wear...like they do their hair and everything. And sometimes they say like hey, how come you can't do my hair and I say I have the hijab on. But I realize that one day everybody's going to die, so I believe that life is a test and that when you die Allah's going to test you again, so either you go to jannah or paradise.

Ishrat: Like they're always like take off your the hijab. And I always disagree, it's part of who I am so I can't just take it off. And like I started in grade four and my recent friends are always like how you should take it off; I want to see how your hair looks; can you please take it off, please. I'll give you my candy or something. I'm like it's not that, it's not like something to be bribed on. It's just part of who you are.

Ayesha: I feel, I don't know, I feel kind of weird because before I used to have my hair open and now I just have it all covered. And then, after I feel kind of proud of myself that I wear the hijab because it makes me feel good.

The literature review indicated that American Muslim women find themselves in a struggle to be a part of the American culture and conform to the fashion norms as well as the American Muslim community and dress in ways considered appropriate in Islam. This position influences their choice of clothing and also the choice to adopt the hijab (Droogsma, 2007). However more and more women are wearing the hijab as an important part of their identity. Many women see the hijab as empowering. It gives them a unique identity. They felt control over their bodies and felt connected with the larger Muslim community. They felt more attached to their religion and it helped them develop 
self discipline. Besides providing a distinct identity, the hijab also is a symbol of the

Muslim community (Ruby, 2006). The girls seem to be experiencing similar feelings of freedom from confirming to the fashion norms of majority culture as well as pride in having a unique identity for themselves.

The Media

There was also a general consensus among the girls about the fact that Islam and Muslims are represented negatively by the media and this affects the thinking of general public. They felt frustrated and angry while discussing the way Muslims are portrayed by the media.

Aleena: I think it's not exactly how people think always. That's not where the problem generates or originates. It is actually the media, it portrays like such a bad image of Muslims and you know it's so disgusting to know that, I mean it's not people's fault. It's like the media, they just make everything seems so...they just put us in positions where you feel like you're alone, that the world's going to turn on Muslims and you get the sense where you're like kind of scared. It does get me frustrated, I mean you get frustrated knowing that there are people out there who think that if you're a Muslim then you have to have some bad role in life or you're going to hurt someone or bomb. It's really frustrating. When people see us they immediately remember terrorists and it bothers me that on the news incidents happen and it suddenly goes towards Muslims and gives Muslims a negative, you know, outlook basically or an image. It ruins our image. I mean yes there are certain people who destruct our image, and yes sometimes they could be Muslim, but I meant here are other you know religions, other cultures that ...I mean being Muslim is not a crime. And sometimes people say that it is because there's so many terrorists that are supposed to be Muslim, they think as if you're Muslim you're going to obviously be a terrorists or you're going to be involved in some kind of crime when you grow up, especially for men. Even though wearing the hijab it still portrays your Muslim individuality.

Sumaiya: Sometimes people they make the hijab as a joke. We see on TV, they sometimes make fun of the hijab; people wear it that are not necessarily Muslim and they like, it makes me sick to know that that's how they think of us and stuff like that. We're normal people, we just believe in Allah. 
Ishrat: the other day I was watching a movie and I saw that the bad guys were always wearing like head coverings and I got really mad that why are they showing the bad guys as Muslims. And I notice that in a lot of movies that the bad guys are always praying or something and then the next thing you know they're like bombing a building. And I got really mad.

The literature review clearly indicated that the representation of the media on the veil of the Muslim woman overlooks the complex social phenomena behind the decision to adopt the hijab and the different meanings it has for different Muslim women. This representation of Muslim women and the overemphasis on the hijab may create misconceptions amongst the Western societies about the Muslim women and Islam in general (Bullock and Jafri, 2000).

The hijab has been viewed by the Western cultures as symbols of oppression of women in the Muslim world. (Cloud, 2004 in Droogsma, 2007). The media plays a major role in determining stereotypes about Muslim women in North America. Images of covered women have often been used to illustrate the "backwardness" of Muslims and the subordination of women in Muslim societies (El Guindi, 1999; Steet, 2000 in Droogsma 2007). According to Ruby (2006), many studies have shown that the image of the Muslim woman portrayed by the dominant North American media is that of an "oppressed and passive the hijab wearer" (Ruby,2006). The hijab has come to be seen as a symbol of Muslim world and is associated with "religious fundamentalism and extremism" (Zine 2006). Due to the tragic events of September 2001, misunderstanding about the Muslim community has increased and little has been done to focus on the positive aspects of Islam (Ahmed \& Szapara, 2003). 


\section{EXPERIENCES: LIVING WITH THE HIIAB}

The girls talked about many experiences in and out of school. They narrated both positive and negative experiences. First we will look at the out of school experiences. One positive incident narrated by Aleena is when she was in her store with her mother and a friend of a customer started swearing while talking to him, this customer pointed out that there are women in the store and stopped hi friend from using bad language. She feels that this customer saw they were in the hijab and out of respect for them he stopped hi friend. She said she generally feels respected when she wears her hijab and says that the hijab gives out the message that one is religious and evokes respect from people.

Aleena: It made me feel good that there were actually people out there who will see you and respect you whether it's because you're a kid or because you're in the hijab or whatever. But there are people who will look at you when you're wearing the hijab and respect you and they'll know that you're the type of person that is religious or... and it does get to show that you're a good person.

A negative out of school experience reported by Aleena was about when she was at a swimming pool and was denied entry because she had worn long pants and a long. tee-shirt. She said because she is a Muslim she is supposed to cover her entire body and she cannot wear the regular swimming costume. She felt offended and says that just because she is following her religion she should not be stopped from activities that she enjoys. In the literature review we have seen that Muslim girls who adopt the hijab find it helpful in avoiding undue male attention. However girls who do not confirm to the fashion norms of the popular culture face exclusion (Zine, 2006).

Sumaiya narrated an incident when she was at a swimming pool and was dressed in long tee-shirt, pants and was wearing the hijab. A boy came up to her and ridiculed the 
Islamic way of greeting one another. She felt offended and said that the greeting has religious meaning and people should say it with respect.

The girls also narrated some positive and negative experiences in schools. As we have seen in the literature review, one of the purposes of education is to develop mutual tolerance and respect for other cultures and religions so that everyone can actively participate in a free society (Nowak, 2001 cited in Smith, 2005). Since the Canadian landscape is becoming increasingly multicultural, children from different cultures and religious backgrounds come together in schools.

The girls said that in school sometimes they can tell that some students are thinking negative about them through their facial expressions. They also reported students calling them "terrorist".

Sumaiya: they are like really rude; they think you're an alien from a planet or something. People call you terrorists, something like that and say oh you're going to bomb the school some day. I'm like I wear the hijab, it's not like I'm a bad person.

Similar experience was narrated by Ishrat when one of her friends asked her why are terrorists Muslims. She explained to her friend that not all Muslims are terrorists. She said she felt very bad and said that the negative media attention on Muslims have created a general feeling amongst people that most Muslims are terrorists.

Aleena narrated an incident where she wanted to help a girl from special education but this girl refused to be friend with her as she was a Muslim. The girl said that her parents had told her not to be friends with Muslims in the school as they had bombed their country. Aleena says she was shocked and offended by the girl's attitude.

Aleena: I was shocked to find out that parents, like some parents would actually like teach their child to stay away from another country because some people, some sinners from that religion have ruined it for everyone else. But I mean it was 
very disappointing and I think that's one of my worst experiences because that was something that I mean that was like really offended me that actually it's not only media but there's some parents that you know would teach their children to do something like that.

In the literature review we have seen that the negative media attention on the Muslims has an impact on people and it has developed a general fear of Muslims. Due to the tragic events of September 11 the misunderstanding about the Muslim community has increased and little has been done to focus on the positive aspect of Islam (Ahmed \& Szapara, 2003).

Ayesha reported an incident where some boys at her school told her she cannot play basketball as she was wearing the hijab and that would obstruct her from playing the game. This incident and Aleena's swimming pool experience brings out an important issue of these girls' participation in sports activities. According to the girls the hijab has never been a problem for them and has never stopped them doing what they want. However, the expected ways of dressing for certain sports can restrict these girls' participation in many sports activities.

The girls also talked about many positive experiences in the school. They said most of their teachers and friends understand why they wear the hijab and support them. Aleena talked about an incident where she said she used to be bullied in school but since she has started wearing the hijab the bullying has stopped.

Aleena: I think mostly probably because I started wearing the hijab and that just represented my religion so they started to respect me more.

Another type of experience that Aleena talked about was in the form of the expectations people had of them and the feeling amongst these girls that because they 
wear the hijab they had to be extra cautious of their behavior as their behavior may affect what people generally think about Muslims.

Aleena: I mean there are some girls in my class that despite wearing the hijab they will misbehave and you know they'll go crazy and you know they will not act as if they're wearing the hijab. So maybe they're not wearing the hijab for the right reasons or they're not fulfilling their duty as a Muslim or as wearing the hijab. And so the teachers get shocked when seeing like a girl that looks so disciplined wearing a the hijab.

Aleena thinks that girls in general should behave themselves in public and more so when you are wearing the hijab. This reflects the way she has been brought up. Many Muslim families bring up their daughters in this manner, teaching them to be more disciplined in their behavior and talk. In a study conducted by Zine (2006) on the veiling practice of Muslim girls in an Islamic school found that the participants felt that it was their responsibility to represent Islam positively wherever they went and so they had to be careful of what they said or did as their actions would be generalized as representative of the entire Muslim population.

Response to the experiences

The girls showed a positive attitude and believed that no matter what experiences they have they will not quit wearing the hijab.

Aleena: Like I mean I know that as negative as some people's thoughts can get, there are people who look at you with respect. I mean there are negative experiences that I've been through but when I look at the positive experiences it makes me feel really good about myself and about wearing the hijab.

Ayesha: I feel like proud, like when I wear the hijab because that's showing my religion. 
Ishrat: I feel proud that I am unique and it shows who I am, basically that I am a Muslim.

The girls' determination and faith in their religion was clearly very strong. They believed that the hijab was for their own good and so they will never give it up. 


\section{IMPLICATIONS OF THE STUDY}

This research identifies some important issue faced by Muslim girls who wear the hijab. The literature review revealed that there is a general misconception about the hijab and is seen as oppressive and forced on Muslim woman. However many studies have shown that it is not necessarily seen as oppressive by Muslim women themselves. In fact many find it liberating and helpful in maintaining their identity. The media representation of the Muslim community was seen as misleading by the girls in the research. They felt that the media focus on the negative actions of some Muslims has resulted in a generalized feeling of fear and hatred towards all Muslims. All the girls in the study said that the hijab has been a positive experience for them and has become a part of their identity. I found that the feeling amongst the girls that the hijab represents the Islamic culture and that it is their responsibility to ensure that it is represented positively was very strong. These girls seemed greatly affected by the extensive media attention on the Muslim community, mostly depicting it in a negative way. They have had good and bad experiences with it but they chose to focus on the positive experiences and say that they would never give up their the hijab as it is required by their religion and also is a marker of a Muslim identity. This positive attitude amongst these young girls was extraordinary. Schools play a major role in creating awareness and building tolerance towards each other as students from many cultures and social backgrounds attend them. They need to be more accepting of the cultural values of all the students and help promote unity in diversity. 
The study was conducted with a very small sample, thus the finding cannot be generalized to the larger population. Also due to time constraints, not all issues related to the hijab could be focused on in detail. The views and perceptions of the parents, peers and teachers could provide rich data in helping to develop a deeper understanding of the girls' reason and experiences of wearing the hijab. The hijab is globally worn by many Muslim women of all ages and the scope and need to explore this topic further is crucial. 


\section{REFERENCES}

Ahmed, I. \& Szpara, M, Y. (2003). Muslim Children in Urban America: the New York City Schools Experience. Journal of Muslim Affairs, 23(2), p. 295-301

Arnett, Jeffrey Jenson (1995). Broad and narrow socialization: The family in the context of a cultural theory. Journal of Marriage and the Family, 57 (3), p.617

Atasoy, Y. (2006). Governing women's morality: A study of Islamic veiling in Canada. European Journal of Cultural Studies, 9 (2), p. 203-221

Bisin, A., Patacchini, E., Verdier, T. \& Zenou, Y. (2007). Are Muslim Immigrants Different in Terms of Cultural Integration? Discussion Paper No. 3006 presented at The Institue for the Study of Labor (IZA) in August 2007

Berg, Bruce L. (2001). Qualitative Research Methods for the Social Sciences. $4^{\text {th }}$ Edition. Boston, Mass; London. p. 33.

Bullock, K, H. \& Jafri, G, J. (2000). Media (Mis)representations: Muslim Women In the Canadian nation. Canadian Woman Studies, 20 (2); p. 35.

Cadge, W., Ecklund, E, H. (2007). Immigration and Religion. Annual review of sociology, 33, p. 359-379

Census 2006. Retrieved from:

(http://www12.statcan.ca/english/census06/analysis/immcit/foreign_born.cfm)

Chan, E. (2006). Teacher experiences of culture in the curriculum. Journal of curriculum studies, 38(2), p. 161-176

Creswell, J. (2003). Research Design: Qualitative, Quantitative and Mixed Methods Approaches. Sage Publications 
Droogsma, R. A. (2007). Redefining Hijab: American Muslim Women's Standpoints on Veiling. Journal of Applied Communication Research, 35(3), p. 249-319

Freedman, J. (2007). Women, Islam and Rights in Europe: beyond a universalist/ culturalist dichotomy. Review of International Studies, 33 p. 29-44

Gereluk, D. (2005). Should Muslim Headscarves be banned in French Schools? Theory and Research in Education 3(3), p. 259-271.

Hennessy, E. \& Heary, C. (n.d.). Exploring Children's Views Through Focus Groups. In Greene, S. \& Hogan, D. (Eds.). (2005). Researching Children's Experience: Approaches $\&$ Methods, p. 236-251. Sage Publication Ltd.

Hoot, J. L., Szecsi, T. \& Moosa, S. (2003). What Teachers of Young Children Should Know About Islam. Early Childhood Education Journal, 31(2), p. 85-90

Hussein, S. (2007). The Limits of Force/ Choice Discourses in Discussing Muslim Women's Dress Codes. Transforming Cultures e-Journals, 2 (1).

Peek, L (2005). Becoming Muslim: The Development of a Religious Identity. Sociology of Religion, 66 (3), p. 215-242.

Read, J, G. \& Bartkowski, J, P. (2000). TO VEIL OR NOT TO VELL? : A Case Study of Identity Negotiation among Muslim Women in Austin, Texas. Gender \& society, 14 (3), p. $395-417$

Ruby, T. F. (2006). Listening to the voices of hijab. Women's studies international forum, 29, p. 54-66

Schimdt, G (2004). Islamic Identity Formation among Young Muslims: The Case of Denmark, Sweden and the United States. Journal of Muslim Affairs, 24 (1), p. 31-45. 
Shadid, W. \& Koningsveld, P, S, V. (2005). Muslim Dress In Europe: Debates On The Headscarf. Journal of Islamic Studies, 16 (1), p. 35-61.

Sheriff-Ross, F., Tirmazi, T. M., Walsh, T. R., (n.d.). Cultural and Religious Contexts of Parenting by Immigrant South Asian Muslim Mothers. In Lansford, J. E., DeaterDeckard, K., Bornstein, M. H. (Ed.). (2007). Immigrant Families in Contemporary Society. p. 195-209. The Guilford Press.

Smick, E. (2006). Canada's Immigration Policy. Council on Foreign Affairs. Retrieved from, http://www.cfr.org

Smith, E, D. (n.d.). The Conceptual Practices of Power: A Feminist Sociology of Knowledge. In Gamer, R. (Ed.). (2000). Social Theory: Continuity \& Confrontation: A Reader. p. 478-485. Broadview Press Ltd.

Smith, Rhona K. M. (2007). Religion and education: a human rights dilemma illustrated by the recent 'headscarf cases'. Globalisation, Societies and Education, 5(3), p. 303-314

Strauss, A \& Corbin, J. (1998). Basics of Qualitative Research: Techniques \& Procedures for Developing Grounded Theory. Sage Publication

Subedi, B. (2006). Preservice Teachers' Beliefs and Practices: Religion and Religious Diversity. Equity \& Excellence in Education, 39(3), p. 227 - 238

The Human Rights and Equal Opportunity Commission Report (2004). Retrieved from: http://humanrights.gov.au/racial_discrimination/isma/research/index.html\#5

Thomas, N M. (2005). On Headscarves and Heterogeneity: Reflections on the French Foulard Affair. Dialectical Anthropology, 29, p. 373-386

Universal Declaration of Human Rights. Retrieved from: http://www.un.org/Overview/rights.html 
Ziegler, R. (2007). The French 'Headscarves Ban': Intolerance or Necessity? The John Marshall Law Journal 40(2), p. 101-129.

Zine, J (2000). Redefining Resistance: towards an Islamic subculture in schools. Race Ethnicity and Education, 3 (3), p.293-316

Zine, J. (2006). Unveiled Sentiments: Gendered Islamophobia and Experiences of Veiling among Muslim Girls in a Canadian Islamic School. Equity \& Excellence in Education, 39(3), p. 239-252 


\section{APPENDICES}

Appendix A

\section{Ryerson University \\ Consent Agreement: Focus Group/ Personal Interview}

Understanding Young Muslim Girls' Reasons for and Experiences of Wearing the Hijab

Your child is being asked to participate in a research study. Before you give your consent for your child to be a volunteer, it is important that you read the following information and ask as many questions as necessary to be sure you understand what you will be asked to do.

\section{Investigators:}

Principal Investigator: Farheen Khan

Research Supervisor: Dr. Mehrunissa Ahmed Ali

\section{Purpose of the Study:}

This study is conducted to understand the reasons of young Muslim girls for wearing the hijab and what have been their experiences in their schools as a result of wearing the hijab. The number of subjects for this study would be 5 girls aged 11-13 years, wearing hijab and attending a Canadian Public school.

\section{Description of the Study:}

Procedure for Personal Interview

I will interview your child. In the interview I will talk to you child about the discussions in the focus group in details. They can add to or share more if they wish. The questions will be about why they wear the hijab and what have been their experiences of wearing it in detail. This will go on for approximately for an hour. This will be audio taped. I will maintain the confidentiality of everything they say.

Procedure for Focus Group

Your child will participate in a Focus Group discussion of about five girls, to be held in a meeting room in my building. I will introduce a topic or ask a question and they will be asked to discuss it and share their opinion about it. The topics will be about why they wear the hijab and what have been their experiences of wearing it. This will go on for approximately for an hour. This will be audio taped. I will maintain the confidentiality of everything they say, and I will remind all other participants to do so as well. However, I cannot promise that they will do so.

What is Experimental in this Study: None of the procedures or questionnaires, used in this study are experimental in nature. The only experimental aspect of this study is the gathering of information for the purpose of analysis. 


\section{Risks or Discomforts:}

This potential risk in the study is that due to the nature of the questions involved the participants might feel judged and may not reveal their true opinion or experiences. Also someone could recall an unpleasant experience. In the case of discomfort all the participants will be told before the start of the study that they can discontinue participation during any point in the study either temporarily or permanently.

\section{Benefits of the Study:}

This research aims to understand the viewpoints of young girls about the hijab and it gives them an opportunity to voice their opinions about it and talk about their experiences of wearing the hijab in Canadian Public Schools. This research also aims to enhance the understanding of educators in particular about why these girls wear the hijab and encourage greater acceptance of cultural differences.

I cannot guarantee, however, that you will be benefitted from participation in this study.

\section{Confidentiality:}

Only the principal investigator and the faculty supervisor will have access to the data. The computer copy will be protected by a password known only to the researcher and the supervisor. Paper copies of the data will be kept locked in a safe place only accessible to the researcher and the supervisor in the researcher's home. All data will be destroyed after two years of completion of the study. None of the participants will be indentified by their real names unless they ask to do so.

Incentives to Participate: The participant will not be paid to participate in this study.

Voluntary Nature of Participation: Participation in this study is voluntary. Your choice of whether or not to participate will not influence your future relations with me or Ryerson University. If you decide to participate, you are free to withdraw your consent and to stop your participation at any time. At any particular point in the study, you may refuse to answer any particular question or stop participation altogether.

Questions about the Study: If you have any questions about the research now, please ask. If you have questions later about the research, you may contact:

Principal Investigator: Farheen Khan

Graduate Student: Masters in Early Childhood Studies, Ryerson University.

Phone: 416-747-7377

Research Supervisor: Dr. Mehrunissa Ahmed Ali

Phone: 416-979-5000 ext: 6330

If you have questions regarding your rights as a human subject and participant in this study, you may contact the Ryerson University Research Ethics Board for information.

Research Ethics Board

c/o Office of the Vice President, Research and Innovation

Ryerson University

350 Victoria Street

Toronto, ON M5B 2K3 


\section{Agreement:}

Your signature below indicates that you have read the information in this agreement and have had a chance to ask any questions you have about the study. Your signature also indicates that you agree that your child participates in the study and have been told that you can change your mind and withdraw your consent to participate at any time. You have been given a copy of this agreement.

You have been told that by signing this consent agreement you are not giving up any of your legal rights.

Name of the Parent Guardian of Participant

Signature of Parent Guardian of Participant Date

Signature of Investigator

Date

Name of Child

Consent for Audio Taping

I will be audio taping the interview for future analysis. Please indicate whether you agree that your child be audio taped.

I agree

I do not agree

Signature of the Parent/Guardian of the Participant Appendix B 


\section{Assent Form: Focus Group/Personal Interview}

Understanding Young Muslim Girls' Reasons for and Experiences of Wearing the Hijab

You are being asked to participate in a research study. Before you give your consent to be a volunteer, it is important that you read and understand the following information and ask as many questions as necessary to be sure you understand what you will be asked to do.

This study is conducted to understand the reasons of young Muslim girls for wearing the hijab and what have been their experiences in their schools as a result of wearing the hijab. I am conducting this study to write a paper for my Master's program. After I have completed it, I may also use it to write an article in a journal.

\section{Procedure:}

First, you will participate in a Focus Group discussion of about five girls, to be held in a meeting room in my building. I will introduce a topic about why you wear the hijab and what have been your experiences of wearing it and I want you to discuss it and share your opinion about it. This will go on for approximately for an hour. This will be audio taped. I will maintain the confidentiality of everything you say, and I will remind all other participants to do so as well. However, I cannot promise that they will do so.

A few days after the focus group, I will interview you individually, in the same room or at your home, just to talk about what we discussed in the focus group and give you an opportunity to add more if you wish. The interview will be of approximately one hour and also audio-taped. If you do not want to be audio-taped in your individual interview, I will just take notes as I talk to you. I promise to maintain confidentiality of whatever you say during the interview.

Your name will be changed in my written report.

If, at any point of the study, you feel uncomfortable you may discontinue either temporarily or permanently. If you do not wish to answer any question you may say so.

Only I and my university professor will have access to the data. The computer copy will be protected by a password known only to me and my supervisor. Paper copies of the data will be kept in a safe place only accessible to me and my supervisor. All information you give me will be kept only for two years, and then destroyed.

Participation in this study is voluntary. Your choice of whether or not to participate will not influence your future relations with me, or Ryerson University. If you decide not to participate, you are free to say now; or you can stop participating for a short period at any time; or stop your participation altogether. 
Name of Participant (please print)

Signature of Participant

Date

Signature of Investigator

Date

\section{Consent for Audio Taping}

During the interview, I will audio tape the discussion for future analysis. Please indicate whether you agree to be audio taped.

I agree

I do not agree

Signature of the Parent/Guardian of the Participant 
Appendix C

Focus Group Questions

1. Why do you think Muslim women and girls wear hijab?

2. What is the purpose of hijab?

3. What are the stereotypes regarding the hijab?

4. What have been some of your experiences in schools when you wear the hijab?

Interview Questions :

1. When did you start wearing the hijab and why?

2. How do you feel when you wear the hijab?

3. What do you family and friends say about it?

4. Have you considered not wearing the hijab? Why and why not? 